\title{
Enlightened Religion: From Confessional Churches to Polite Piety in the Dutch Republic
}

\author{
Joke Spaans and Jetze Touber
}

European religious culture changed in the transition from the seventeenth to the eighteenth century. We have known this for a long time. Ernst Troeltsch, in his Die Bedeutung des Protestantismus für die Entstehung der modernen Welt (1906), famously hinted at a reconceptualization of religion at this juncture, especially within Protestant areas such as the Dutch Republic and England. Here Troeltsch saw the roots of a 'New Protestantism,' essentially the Kulturprotestantismus of his own time, a Protestantism that had turned away from the confessional definitions of the sixteenth century. Through its absorption of elements from Renaissance humanism, Anabaptism, and spiritualism this modern Protestantism had become a personal conviction for its adherents, rather than the religious system that had offered early modern princes and political elites legitimation for their confessional states. More influential, however, was Paul Hazard's Crise de la conscience Européenne (1680-1715) (1935). In this book he traced the transformations in this same crucial period far beyond the sixteenth century, back to classical paganism and its revival in the Renaissance, which bore fruit in the-anti-Christian-French Revolution. Peter Gay's interpretation of the Enlightenment, whose first part was tellingly entitled The Rise of Modern Paganism (1966), expanded on this view, shifting the emphasis from antiquity and the Renaissance to the secularizing tendencies of the Enlightenment. With hindsight we can safely state that these authors projected their own ideals-Troeltsch of an openminded, modern Protestantism, Hazard and Gay of a secular modernity—back into the past.

The perception of a decisive shift in worldviews sometime around 1700 has persisted, but how to interpret it, especially with regard to religion, has remained an open question. Troeltsch, despite his necessarily schematic representation of historical processes in his short overview of the relation between Protestantism and progress, did not limit himself to religious or even intellectual history in the aftermath of the Reformations of the sixteenth century and the early modern pre-history of his modern age. His analysis encompasses a wide range of environments and debates where religion could have made a difference: politics, social and economic developments, legal systems, and

(C) JOKE SPAANS AND JETZE TOUBER, 2019 | DOI:10.1163/9789004389397_002

This is an open access chapter distributed under the terms of the prevailing CC-BY-NC License at the time of publication. 
gender relations. It culminates, however, in a claim that religion itself had become more modern —in a sense: more 'religious' — around 1700. Building upon Troeltsch's informed hunches, the contributions to this book show how the intellectual culture of the later seventeenth century was host to a number of conversations between people with a wide variety of philosophies and worldviews and who came from different walks of life. These dialogues exerted an impact on religion and the state and all that these terms implied in early modern societies. Across all of Christendom, the topics under discussion in this period show marked similarities, and at the same time separate debates raged over their applicability within individual polities. Case studies in this volume focus on the Dutch Republic, where discussion culture was less constrained and therefore more inclusive than in most other countries. ${ }^{1}$

Unlike Troeltsch, who analysed the impact of Protestantism on various sections of society but not the other way around, the authors of this volume foreground this more inclusive conversational aspect of intellectual life. Like the fruits of any conversation, the discoveries of the seventeenth century, the debates they engendered, and the reflections that those in their turn invited went each and every way. They did not so much produce firm conclusions as explore possibilities. They often transcended the boundaries of the topics Troeltsch used for his analysis, as they addressed seventeenth-century rather than modern concerns. We therefore eschew here any claim of a unilinear Enlightenment project evolving towards modernity. Neither do we take as our point of departure the 'culture wars' or any modern concern about the relation between religion and secularism. Instead, like Troeltsch, we look first and foremost at religion in the long aftermath of the Reformation. Trying to 'see things their way' may eventually be a more fruitful approach towards calculating the lasting influence of the developments that Paul Hazard proactively declared a 'crise de la conscience' than an exclusive focus on those aspects and persons that we would consider adumbrations and precursors of modernity can hope to accomplish. ${ }^{2}$

The chapters that follow are concerned with changes in religion's conceptualization and the new discursive spaces where the nature of Protestantism came to be discussed by the end of the seventeenth and the beginning of the eighteenth century. Late humanism and the Enlightenment both played a part

1 Most of the articles are expanded versions of lectures presented at a conference held in Utrecht, January 21-23, 2015, which concluded the research programme Faultline 17oo: Early Enlightenment Conversations on Religion and the State. This project was made possible by a generous subsidy from the Netherlands Organisation for Scientific Research (NWO).

2 Cf. Alister Chapman, John Coffey and Brad S. Gregory, Seeing Things Their Way: Intellectual History and the Return of Religion (Notre Dame, Ind., 2009). 
in these debates. Individual thinkers from a wide spectrum, from the highly sceptical Pierre Bayle to the orthodox Wilhelmus à Brakel, worried about and eventually dissolved the logic underpinning confessional states and churches and explored the more individual and 'polite' forms of religion that we have come to associate with the Enlightenment. Unlike most of the respectable, still growing body of scholarship on the relation between religion and the Enlightenment, this volume does not focus on the resilience of religion despite growing criticism - of its metaphysics, of the authority of the Bible or the Church as an institution and its relation to the State-or on these criticisms per se, but rather on the cultural changes that produced them, how they produced them, and the religious cultures they provoked. ${ }^{3}$

The interlocked conversations about the early modern conundrums of politics, intellectual culture, and religion defy attempts to formulate simple and straightforward interpretations of the transformations produced by this period of crisis. Specialization has not been kind to the study of this complex process. Historians have often focused on separate elements. Over the last half century historical research on early modern religion has been dominated by the confessionalization theory, a theory eminently suited to analyse the political implications of either religious homogeneity or religious diversity in the early modern period. Initially the concept of confessionalization was used first and foremost in a political and socio-historical approach towards religion and religious settlements, and covered the policies used by politicians and ecclesiastics to enforce religious conformity. ${ }^{4}$ Gradually, however, historians came to realize that, as essential as government policies were for early modern religious settlements and for the shape of ecclesiastical structures, they did not explain all the observable changes. Devotional religious cultures flourished in the later seventeenth century, in Protestant as well as in Catholic countries, with or without state support. Piety was often considered a badge of distinction, and devotional exercises, both in the form of public ritual and the deeply personal habits of the heart, appear to have been exceedingly popular. Vibrant religious cultures became tightly interwoven with local and national identity politics. This entanglement could not have happened only in a top-down

3 For the development of this field see Sheridan Gilley, 'Christianity and Enlightenment: An Historical Survey,' History of European Ideas 1 (1981), 103-22; Simon Grote, 'ReviewEssay: Religion and Enlightenment,' Journal of the History of Ideas 75 (2014), 137-60; William J. Bulman, 'Enlightenment for the Culture Wars,' in: God and the Enlightenment, ed. William J. Bulman and Robert G. Ingram (New York, 2016), pp. 1-41.

4 Thomas A. Brady Jr, 'Confessionalisation: The Career of a Concept,' in: Confessionalization in Europe, 1555-1685: Essays in Honor and Memory of Bodo Nischan, ed. John M. Headley, Hans J. Hillerbrand, and Anthony J. Papalas (Aldershot, 2004), pp. 1-20. 
fashion; it presupposed the cooperation of the 'common people. ${ }^{5}$ Research on the confessional age has consequently broadened its scope to allow for more complex dynamics operating within societies. This more expansive purview, however, has done little to assuage another interpretive incongruence, namely between the social forces of confessionalization and the intellectual forces of Enlightenment thought. Confessionalization theory operates within the field of socio-cultural history, Enlightenment thought within that of intellectual history. As yet it is far from clear how the two developments may have been related, and how religion figured in this relation.

A key concept in the intellectual history of early modern religion is toleration. Enlightened thought has always played an important part in the study of its emergence. ${ }^{6}$ In the early modern period freedom of religion was as yet only an ideal on a far horizon, shared among a rather select group of Enlightened thinkers. Controversy withered, as did the Wars of Religion. In most European countries the Reformation and Counter-Reformation had produced confessionally fairly homogeneous populations through settlements between princes and established churches. This was especially the case in Scandinavia and the southwestern portion of the continent, but less so in the Holy Roman Empire, the Swiss Confederacy, the Low Countries, and Great Britain. ${ }^{7}$ Here governments, faced with religious diversity among their subjects, experimented with toleration. Initially they did so predominantly as a matter of law enforcement:

5 This new outlook appears in Heinz Schilling, 'Confessional Europe,' in:Thomas A. BradyJr etal., eds., Handbook of European History 1400-160o. Late Middle Ages, Renaissance and Reformation, 2 vols. (Leiden, 1995), 2:641-81, and above all R. W. Scribner, For the Sake of Simple Folk: Popular Propaganda for the German Reformation (Cambridge, 1981), and id., Popular Culture and Popular Movements in Reformation Germany (London, 1987). Instructive case studies are Craig Harline and Eddy Put, A Bishop's Tale: Mathias Hovius among his Flock in Seventeenth Century Flanders (New Haven, 200o); Wietse de Boer, Conquest of the Soul: Confession, Discipline, and Public Order in Counter-Reformation Milan [Studies in Medieval and Reformation Traditions, vol. 84] (Leiden, 200o); Ronnie Po-Chia Hsia, The World of Catholic Renewal 1540-1770 (Cambridge, 1998); Karen E. Carter, Creating Catholics: Catechism and Primary Education in Early Modern France (Notre Dame, Ind., 2011); Margo Todd, The Culture of Protestantism in Early Modern Scotland (New Haven, 2002). For the Dutch Republic: Judith Pollmann, Religious Choice in the Dutch Republic: The Reformation of Arnoldus Buchelius (1565-1641) (Manchester, 1999); Willem Frijhoff, Embodied Belief: Ten Essays on Religious Culture in Dutch History (Hilversum, 2002).

6 E.g., John Marshall, John Locke, Toleration and Early Enlightenment Culture: Religious Intolerance and Arguments for Religious Toleration in Early Modern and 'Early Enlightenment' Europe (Cambridge, 2006); Hans Erich Bödeker et al., eds., Discourses of Tolerance and Intolerance in the European Enlightenment (Toronto, 2009); Perez Zagorin, How the Idea of Religious Toleration Came to the West (Princeton, N.J., 2013); Jonathan Parkin and Timothy Stanton, eds., Natural Law and Toleration in the Early Enlightenment (Oxford, 2013).

7 Diarmaid MacCulloch, Reformation: Europe's House Divided 1477-1700 (London, 2003). 
religious diversity was perceived as a threat to political and social stability and toleration as an unwelcome necessity. ${ }^{8}$

Theorizing about religious toleration at the turn of the eighteenth century was anything but 'enlightened' in the modern sense, as it perpetuated forms of discrimination and exclusion. Neither was it 'modern' in the sense of advocating what we call secularization. Eventually, however, and despite lingering popular discontent and occasional bouts of persecution, Enlightened ideology became happily married to political expediency and helped shape a culture of tolerant politeness. From Protestant Prussia to Catholic Austria, Enlightened monarchs lifted the obstacles for political and cultural participation by religious minorities that had always been part and parcel of their confessional states. They did so not merely out of Enlightened largesse, but rather out of the awareness that the traditional practice of discrimination against minorities left unused their social, economic, and intellectual potential. Novel ideas of citizenship, beginning to be conceived not as a cluster of jealously guarded privileges granted to an established elite but as an entitlement due every man, woman, and child willing and able to contribute to the well-being of society, started to emerge. ${ }^{9}$

The Enlightenment has long been considered a force not only towards religious toleration but also the disenchantment of the world, and consequently it has been regarded as the intellectual foundation of a unilinear process of secularization. Supposedly, the impact of corrosive 'radical Enlightened' thought was buffered or stalled for some time by the influence of a moderate Enlightenment and the rise of forms of 'reasonable religion', but in the long run secularization was to be irreversible. It has been convincingly argued that

8 Difference and Dissent: Theories of Toleration in Medieval and Early Modern Europe (Lanman, 1996); John Christian Laursen and Cary J. Nederman, eds., Beyond the Persecuting Society: Religious Toleration before the Enlightenment (Philadelphia, 1998); Benjamin Kaplan, Divided by Faith: Religious Conflict and the Practice of Toleration in Early Modern Europe (Cambridge, Mass., 2007); Marshall, John Locke (see above, n. 4); Alexandra Walsham, Charitable Hatred: Tolerance and Intolerance in England, 1500-1700 (Cambridge, 2006); Eliane Glaser, ed., Religious Tolerance in the Atlantic World: Early Modern and Contemporary Perspectives (Basingstoke, 2013). On the Dutch Republic: C. Berkvens-Steveling, J. Israel, and G. H. M. Posthumus Meyjes, eds., The Emergence of Tolerance in the Dutch Republic (Leiden, 1997); Henk van Nierop and Ronnie Po-Chia Hsia, eds., Calvinism and Religious Toleration in the Dutch Golden Age (Cambridge, 2002).

9 Derek Beales, Enlightenment and Reform in Eighteenth Century Europe (London, 2005); Lynn A. Hunt, The Enlightenment and the Origins of Religious Toleration (Utrecht, 2011); Rienk Vermij, De geest uit de fles: de Verlichting en het verval van de confessionele samenleving (Amsterdam, 2014). On ideals of citizenship: Willeke Los, Opvoeding tot mens en burger: pedagogiek als cultuurkritiek in Nederland in de 18e eeuw (Hilversum, 2005). 
this conception was an idea projected by late-eighteenth-century philosophers, canonized in the French Revolution and perpetuated by its anticlerical admirers and defenders; it reflected wishful thinking rather than an accurate account of historical realities. ${ }^{10}$ Developments in philosophy and the natural sciences, once considered inimical to traditional Christian religion, usually proceeded from the work of people who considered themselves religious and who did not aim to undermine religion. Orthodox theologians initially decried Cartesianism as a high road to atheism, as it advocated doubt even about the existence of God. It was hailed by other, equally orthodox theologians as a firm foundation for establishing truth, also in religion. Natural philosophers unravelled the mysteries of Creation without arriving at a purely materialist worldview. Most could effortlessly combine their findings with continued adherence to confessional Christianity.11 Others found their discoveries troubling-but a Jan Swammerdam sought solace in radical religion rather than an embrace of materialism. Observations in microscopy that defied integration into a Christian universe were abandoned as insoluble conundrums and did not engender a rejection of that universe. ${ }^{12}$

Not only has the Enlightenment, taken as a project, thus regained a more positive connection to religious history, Enlightenment research has also spilled over into intellectual areas previously neglected in its historiography. The lively interest in philology and antiquities in the seventeenth and eighteenth centuries has long been considered alien to Enlightened concerns, perhaps even relatively harmless. Yet philology may have been the discipline most threatening to religious authority and most conducive to the development of forms of Enlightened Christianity. Textual criticism, not only of Louis Cappel

10 David Sorkin, The Religious Enlightenment: Protestants, Jews and Catholics from London to Vienna (Princeton, N.J., 2008), pp. 311-4.

11 John Hedley Brooke, Science and Religion: Some Historical Perspectives (Cambridge, 1991), pp. 53-81; Rienk Vermij, The Calvinist Copernicans: The Reception of the New Astronomy in the Dutch Republic, 1575-1750 (Amsterdam, 2002); Eric Jorink, Reading the Book of Nature in the Dutch Golden Age, 1575-1715, trans. Peter G. Mason (Leiden, 2010). For the integration of new developments in natural philosophy in biblical exegesis: Bernd Roling, Physica Sacra: Wunder, Naturwissenschaft und historischer Schriftsinn zwischen Mittelalter und Früher Neuzeit (Leiden, 2013).

12 Wiep van Bunge, From Stevin to Spinoza: An Essay on Philosophy in the SeventeenthCentury Dutch Republic (Leiden, 2001); Luuc Kooijmans, Gevaarlijke kennis: inzicht en angst in de dagen van Jan Swammerdam (Amsterdam, 2007); Rienk Vermij, Secularisering en natuurwetenschap in de zeventiende en achttiende eeuw: Reading the Book of Nature (see above, n. 11) (Amsterdam, 1991); id., The Calvinist Copernicans (see above, n. 9); Jorink, Reading the Book of Nature (see above, n. 11); Edward G. Ruestow, The Microscope in the Dutch Republic: The Shaping of Discovery (Cambridge, 1996). 
and Richard Simon but also of a host of 'scripturarians' at the theological faculties in the Dutch Republic and elsewhere, undercut claims of the factual truth of the Bible, the most authoritative text of the time. At the same time the historicizing exegeses of Hobbes and Spinoza proved explosive in both the ecclesiastical and political domains. ${ }^{13}$ Together and often in close conjunction with early modern ethnology, a field that has only recently captured the interest of cultural historians in efforts to create global history and gain a more subtle understanding of the cultural transfers of this period, antiquarianism appears to have been just as important in reshaping the 'early modern worldview' as the usual suspects in radical philosophy and physics. ${ }^{14}$ The title of a recent monograph even makes the somewhat overstated claim that the early-eighteenthcentury encyclopedia of world religions Cérémonies et coutumes religieuses de tous les peuples du monde, edited by Jean Frédéric Bernard and lavishly illustrated by Jean Picart, was a "book that changed Europe."15 Observable change, however, did not take the direction of a complete relativism but tended towards

13 Jonathan Sheehan, The Enlightenment Bible: Translation, Scholarship, Culture (Princeton, N.J., 2005); Dirk van Miert et al., eds., Scriptural Authority and Biblical Criticism in the Dutch Golden Age: God's Word Questioned (Oxford, 2017); Jetze Touber, Spinoza and Biblical Philology in the Dutch Republic (166o-1710) (Oxford, 2018). Cf. Dmitri Levitin, 'From Sacred History to the History of Religion: Paganism, Judaism, and Christianity in European Historiography from Reformation to "Enlightenment,"' Historical Journal 55 (2012), 1117-61.

14 Anthony Grafton, 'Jean Hardouin: The Antiquary as Pariah,' Journal of the Warburg and Courtauld Institutes 62 (1999), 241-67; Peter N. Miller, "The "Antiquarianization" of Biblical Scholarship and the London Polyglot Bible (1653-57), Journal of the History of Ideas 62 (2001), 463-82; Jonathan Sheehan, 'Idolatry, Antiquarianism and the Polemics of Distinction in the Seventeenth Century,' Past \& Present 192 (2006), 35-66; William Poole, The World Makers: Scientists of the Restoration and the Search for the Origins of the Earth (Oxford, 2010); Martin Mulsow, 'From Antiquarianism to Bible Criticism? Young Reimarus Visits the Netherlands. With an Edition of the Travel Diary Fragment of 1720/1,' in: Between Philology and Radical Enlightenment: Hermann Samuel Reimarus (1694-1768), ed. Martin Mulsow (Leiden, 2011), pp. 1-39; J. Z. Buchwald and M. Feingold, Newton and the Origin of Civilization (Princeton, N.J., 2013).

15 Michiel van Groesen, The Representations of the Overseas World in the De Bry Collection of Voyages (1590-1634) (Leiden, 2008); Lynn Hunt, Margaret Jacob, and Wijnand Mijnhardt, The Book that Changed Europe: Picart \& Bernard's "Religious Ceremonies of the World" (Cambridge, Mass., 2010); id., eds., Bernard Picart and the First Global Vision of Religion (Los Angeles, 2010); Joan-Pau Rubiés, 'Theology, Ethnography, and the Historicization of Idolatry,' Journal of the History of Ideas 67 (2006), 571-96; id., 'From Christian Apologetics to Deism: Libertine Readings of Hinduism, 1650-1730,' in: Bulman and Ingram, eds., God and the Enlightenment (see above, n. 3), pp. 107-35; Guy Stroumsa, A New Science: The Discovery of Religion in the Age of Reason (Cambridge, Mass., 2010). 
a heightened interest in natural religion as a foil against which a reasonable Christianity could take on new meaning.

All these developments in the study of 'the' Enlightenment have produced the notion that there was, in fact, not one Enlightenment but rather an 'Enlightenment spectrum.' We have come to consider the period from the late seventeenth to the end of the eighteenth century and even beyond as a historical epoch, marked by Enlightened notions in a great variety of ways, not only varying from one country to the next, but also producing changing fashions in practically all domains of life, from the political and scholarly to the cultural and popular. Enlightenment appears less and less a well-defined project tending towards a secular age and ever more an ongoing conversation across disciplinary and social boundaries that transformed the religious cultures emerging from the Reformations of the sixteenth century. ${ }^{16}$ Participants in these conversations did not belong exclusively to the leisured classes within and outside the academies but were also found among a wider public of people who were well educated, although not always formally so, and who were engaged in various professions, arts, and crafts. Increasingly, we are aware that Enlightened correspondence and conversation included printers, booksellers and librarians, draughtsmen, engravers and painters, instrument makers, cartographers and architects, diplomats and politicians, clergymen and schoolmasters, all those who had stakes in the new discoveries in the various fields where knowledge was being produced. Men (and a few women) from these and similar walks of life entered the conversation. ${ }^{17}$

Religion in the eighteenth century gradually distanced itself from its sixteenth century confessional moulds. Confessional cultures persisted, and with them the political and social advantages for those professing the dominant religion or willing to conform outwardly as a sign of loyalty to the political regime.

16 Sorkin, The Religious Enlightenment (see above, n. 8), pp. 19-21; Roy Porter and Mikulas Teich, eds., The Enlightenment in National Context (Cambridge, 1981); Stefanie Stockhorst (ed.), Epoche und Projekt. Perspektiven der Aufklärungsforschung (Göttingen, 2013); Dale van Kley, 'Conclusion: The Varieties in Enlightened Experience,' in: Bulman and Ingram, God and the Enlightenment (see above, n. 3), pp. 278-316.

17 On knowledge production in skilled artisanal milieus, see Jonathan I. Israel, The Dutch Republic: Its Rise, Greatness and Fall 1477-1806 (Oxford, 1995), pp. 348-51; Deborah E. Harkness, The Jewel House: Elizabethan London and the Scientific Revolution (New Haven, CT, 2007); Patrick O'Brien, ed., Urban Achievement in Early Modern Europe: Golden Ages in Antwerp, Amsterdam and London (Cambridge, 2001), pp. 287-345; James Van Horn Melton, The Rise of the Public in Enlightenment Europe (Cambridge, 2001). In the Dutch Republic: Van Bunge, From Stevin to Spinoza (see above, n. 10), pp. 1-9. On vernacular education and public opinion: Arjan van Dixhoorn, Lustige geesten: rederijkers in de Noordelijke Nederlanden (1480-1650) (Amsterdam, 2009). 
However, as more and more people from different walks of life gained voices in the conversation, the emphasis shifted from doctrine, the specialism of academic theologians and church leaders, to the Christian life. The Protestant embodiment of this new emphasis insisted on a priesthood of all believers and rejected all forms of 'priestcraft,' practiced by ministers who continued to act as if they stood hierarchically above the common faithful. It demanded a living faith, "pious but not churchly"18 — that is, a faith built on a heartfelt conviction bred through study or the experience of saving grace, a faith that rejected devotions imposed by outside agencies as superstition, fanaticism, or enthusiasm. The Dutch Reformed church fostered advanced catechism teaching to create a well-informed church membership and demanded that its ministers coached those unable to study towards a personal, experiential understanding of the faith. Piety remained at a premium, but it became increasingly identified with civic virtues. The result was what contemporaries called 'reasonable religion': a religion that satisfied heart and mind alike, allowed a certain latitude for different interpretations within one's own religious community, and rejected the intolerance towards the state's dissident minorities. Left behind were the previous century's battles between confessions and the squabbles over the new philosophies, discoveries, and interpretations of scripture: the individual conscience became the arbiter of religious choice. ${ }^{19}$

A new, more interdisciplinary type of history of religion is needed to come to grips with this very complex process. This volume, presenting several case studies, aims to give an outline of the most relevant directions such a new religious history should take. The main focus is on the Dutch Republic: religiously the most tolerant polity in Europe during the second half of the seventeenth century, a champion for the cause of international Protestantism, the cradle of the early Enlightenment, and a hub of the Republic of Letters. Moreover, skilled and well-read professionals, artists, and craftsmen, native-born and immigrant alike, abounded in the highly urbanized Dutch population. Most households possessed books, and many could even boast sizeable libraries. In the eighteenth century, discussion of recent literature, from spectatorial periodicals and newspapers, plans for agricultural innovations, and reports of experiments in the natural sciences, to poetry, history, and theology, took

18 Betje Wolf and Aagje Deken put this lapidary characterization in the mouth of the 'Enlightened believer' Stijntje Doorzicht in their correspondence novel Sara Burgerhart, letter 133 .

19 J. A. I. Champion, The Pillars of Priestcraft Shaken: The Church of England and Its Enemies, 1660-1730 (Cambridge, 1993); Euan Cameron, Enchanted Europe: Superstition, Reason \& Religion, 1250-1750 (Oxford, 2010); Joke Spaans, Graphic Satire and Religious Change: The Dutch Republic 1676-1707 (Leiden, 2010). 
place in the omnipresent societies - not only in the cities but even in remote rural villages. These social currents fostered an intensely civic, perhaps philosophically unspectacular but uniquely variegated, popular Enlightenment. ${ }^{20}$ Therefore, instead of limiting their views to either confessional religion or radical philosophy, the authors of the essays in this volume explore how a great variety of early modern cultural formations and intellectual disciplines contributed to changes in the conceptualization of religion and its position within a wider cultural arena, and how, moreover, all these developments fed off of one another. Famously, in the seventeenth century Descartes' 'mathematical' method was imitated not only in mathematics and in physics, but in the then much wider and very comprehensive field of natural philosophy as well, and even in theology. A series of chapters provide in-depth analyses of the interface between new knowledge and views on religion-from the core textual approaches of humanism to the focus of philosophers on the relations between Church and State and the seeds of modern social sciences planted in the encounter with exotic cultures, to a popular culture of catechism teaching and the emergence of church history as a discipline.

This first attempt at mapping out the entangled strands of intellectual and religious history is long overdue. The Dutch case has been mined mainly for its precocious radical Enlightenment, first and foremost in Jonathan Israel's seminal The Radical Enlightenment and its sequels. ${ }^{21}$ It has too easily been assumed, not only by Israel but in most of the literature before and after him, that the churches, and especially the public Church, were unresponsive and even hostile to any form of innovation. ${ }^{22}$ The professors of theology and the ministers of the public Reformed Church are often presented as a monolithic block of conservatives, for whom the emergence of Cartesianism, new political philosophies, critical philological and antiquarian approaches to the Bible, an incipient comparative study of religions, and the discoveries in the natural sciences constituted so many threats to orthodox theology. They are rarely considered to be public intellectuals, although their academic standing and public

20 Wijnand Mijnhardt, Tot heil van 't menschdom: culturele genootschappen in Nederland, 1750-1815 (Amsterdam, 1987); Arno Neele, De ontdekking van het Zeeuwse platteland: culturele verhoudingen tussen stad en platteland in Zeeland 1750-1850 (Zwolle, s.a. [2011]). Jonathan I. Israel, Radical Enlightenment:Philosophy and the Making of Modernity $1650-1750$ (Oxford, 2001); id., Enlightenment Contested:Philosophy, Modernity, and the Emancipation of Man, 1670-1752 (New York, 2006); id., Democratic Enlightenment: Philosophy, Revolution, and Human Rights 1750-179o (Oxford, 2011).

22 E.g., Andrew C. Fix, Prophecy and Reason: The Dutch Collegiants in the Early Enlightenment (Princeton, N.J., 1991); Michiel R. Wielema, The March of the Libertines: Spinozists and the Dutch Reformed Church (1660-1750) (Hilversum, 2004). 
authority uniquely predisposed them for that role. In view of their prominent involvement in the debates of the second half of the seventeenth century, one would expect that they would have given innovation a more nuanced reception than just contestation, and that the cultural and intellectual environment would have been conducive to an adaptation of religious views to new directions in philosophy, discoveries in science and textual scholarship, a socially more complex society, and the growth of global networks: in short, to the various forms of the Enlightenment. Recently a forceful appeal has been delivered to finally fill this lacuna, and several of the authors in this book make a start. ${ }^{23}$

It is all the more timely as comparative studies of religious culture 'around 170o' usually skip the Dutch Republic for want of useful previous studies which are accessible to a non-Dutch audience. A glaring example is Reginald Ward's The Protestant Evangelical Awakening (1992), a magisterial overview of pietist revivals originating in Central Europe, sweeping westwards and eventually developing into the Great Awakenings in the North American colonies. Many of the key figures of this movement had connections to the Dutch Republic, with its high density of theological faculties, practically all of excellent repute, where the Reformed Church vigorously pursued further religious reform, and where evangelical preachers and prophets of revival too wild for their home churches found refuge and often dedicated followings. English, Dutch, and German theologians corresponded and influenced one another through their writings and in personal meetings across borders all over the Protestant world. Yet the Dutch Republic is absent from Ward's narrative as a whole. ${ }^{24}$

23 Sorkin, The Religious Enlightenment (see above, n. 8); Bulman and Ingram, eds., God and the Enlightenment (see above, n. 13). On the Dutch Republic: P. Bange et al., eds., Kerk en Verlichting: voordrachten gehouden tijdens het Windesheim Symposium te Windesheim op 18 november 1989 (Zwolle, 1990); Ernestine van der Wall, 'Orthodoxy and Scepticism in the Early Dutch Enlightenment,' in: Scepticism and Irreligion in the Seventeenth and Eighteenth Century, ed. Richard H. Popkin and Arjo Vanderjagt (Leiden, 1993), pp. 121-41; id., 'Cartesianism and Cocceianism: A Natural Alliance?', in: De l'Humanisme aux Lumières, Bayle et le Protestantisme: mélanges en l'honneur d'Élisabeth Labrousse, ed. Michelle Magdelaine et al. (Paris, 1996), pp. 447-61; id., 'The Religious Context of the Early Dutch Enlightenment: Moral Religion and Society,' in: The Early Enlightenment in the Dutch Republic, 1650-1750: Selected Papers of a Conference held at the Herzog August Bibliothek, Wolfenbüttel 22-23 March 2001, ed. Wiep van Bunge (Leiden, 2003), pp. 39-57; Ernestine van der Wall and Leo Wessels, eds., Een veelzijdige verstandhouding: religie en verlichting in Nederland 1650-1850 (Nijmegen, 2008); Jan Wim Buisman, ed., Verlichting in Nederland 1650-1850: vrede tussen rede en religie? (Nijmegen, 2013).

24 W. R. Ward, The Protestant Evangelical Awakening (Cambridge, 1992); Mirjam de Baar, Ik moet spreken': Het spiritueel leiderschap van Antoinette Bourignon (1616-1680) (Zutphen, 2004); Brigitte Klosterberg and Guido Naschert, eds., Friedrich Breckling (1629-1711): 
The budding literature on Enlightened forms of religion, spreading out from the usual suspects France and Great Britain to the Catholic Habsburg lands, and from an exclusive focus on Christianity to the inclusion of the Jewish haskala, also tends to bypass the Republic. David Sorkin's The Religious Enlightenment: Protestants, Jews and Catholics from London to Vienna (2008) is a good example. Sorkin presents case studies of scholars who introduced novel, Enlightened forms of religion in several confessional contexts and in a variety of Western countries, but not in the Dutch Republic, despite its wellknown role as an entrepôt of Enlightened debate and publishing-and intellectual exchanges among people of a variety of faiths. ${ }^{25}$ Jonathan Sheehan's The Enlightenment Bible (2005) similarly ignores the Dutch Republic even as it surveys the implications of two centuries of philological work on the Bible in northwestern Europe. ${ }^{26}$ Although 'religious Enlightenment' and 'Enlightened religion' are no longer perceived to be oxymorons, in the research in this field the contributions of spokespeople for the Dutch Reformed are sorely missed.

This volume is divided into two parts. The chapters of Part I present surveys of the larger changes in the intellectual landscape, which impinged upon the changing understanding of not only what religion was, but also how it should be evaluated.

In the opening chapter, Henri Krop outlines a programmatic development in the paradigm shift, identified by the Israeli scholar Guy Stroumsa, that led to the modern notion of religions in the plural. This new plural implied the equality of different religions and thereby the imperative of toleration, a key element of the Enlightenment. He traces this development through an analysis of a number of key texts, prominent among them the newly invented encyclopedias. A comparable redimensioning of the traditional sources of Christianity occurred in other areas as well. Jetze Touber explores the contribution of antiquarianism in a case study on Gisbertus Cuper. Over the course of a lifelong correspondence with fellow scholars about history of writing, Cuper came to see the necessity of redesigning the relation of 'world history' to biblical history as a divinely-laid-out, providential path of human development. The expanding spatial parameters of humanity also offered food for thought as well as occasions to experiment with alternative religious communities in the New

Prediger, "Wahrheitszeuge" und Vermittler des Pietismus im Niederlandischen Exil (Halle, 2011).

25 See also: Martin Mulsow, 'Orientalistik im Kontext der sozinianischen und deistischen Debatten: Spencer, Crell, Locke, Newton,' Scientia Poetica 2 (1998), 27-57.

26 Sheehan, Enlightenment Bible (see above, n. 11). 
World. Arthur Weststeijn demonstrates this in his presentation of the dreams of several radical reformers for communities where Enlightened spiritualities could flower, free from the constraints of the confessional state and its endemic conflicts. Martin Gierl analyses the communicative space in which religion was discussed, and shows how theological controversy, more specifically the pietist controversies in the German Empire, developed into new genres and media, in the end changing not only the shape and tone of the conversation but its content as well. Journals and programmatic church histories created religious identity in new ways, but also meshed with Enlightened values of impartiality and improvement and with new means of knowledge production. Albert Gootjes concludes this section with a reconstruction of the activities of the Utrecht Collegie der Sçavanten, an informal scholarly society that played a key role in the evaluation of radical thought in the Republic during the troubled early 1670 s.

After the general themes discussed in Part I, in Part II the case studies of individual thinkers, authors, and artists serve to demonstrate how such figures contributed to this debate and how they found their way into the shifting media landscape. These cases sidestep the canons of church history or the history of philosophy and present intellectuals from what was traditionally called 'the second tier,' men who were entrepreneurs as well as opinion makers and self-proclaimed enlighteners of the general public. Exemplary for this newly emerging class is the etcher Romeyn de Hooghe, whose work can be read as a pictorial commentary on his age. He capped his career with two substantial books, one on the nature of the Dutch Republic, the other on the nature of religion.

The contribution of Frank Daudeij shows how De Hooghe, in his chorography Spiegel van Staat (Mirror of the State), claims for the Dutch a yearning for liberty in politics as well as religion, inbred in the Dutch from their immemorial past and consolidated in customs that preceded and determined later religious regimes. De Hooghe's valuation of custom, although not in itself radical, turns out to have been derived from the works of sceptic authors and satirists and to have some affinity with the political theory of Spinoza, and to have contributed to eighteenth-century notions of the fatherland. Jaap Nieuwstraten's work on the versatile linguist and historian Marcus Zuerius Boxhorn highlights how De Hooghe's modern ideas of fatherland were indeed founded on those of a previous generation. Boxhorn transformed a much older humanist appreciation of the respect for custom in ancient Greece into a defence of the confessional state, yet his belief in the versatility of custom earned him a warm reception among more radical authors who argued that religious regimes should change with the times. 
Trudelien van 't Hof and Jonathan Israel explore the contribution of graphic artists to the unfolding debate on Enlightened religion. Van 't Hof analyses De Hooghe's Hieroglyphica and shows how this enigmatic book reflects a good deal of the contemporary critique of confessional religion, yet does not advocate irreligion. Rather, the etcher problematized religion and invited readers to forge their own informed opinions. Israel demonstrates that Willem Goeree and Arnold van Houbraken, men who in many respects resembled De Hooghe, were much more radical, as their art theory echoes the ideas of the most controversial thinkers of the age. All this may have made them a connecting link between the early phase of the radical Enlightenment and the libertinage érudit of the Huguenot refugees from the second quarter of the eighteenth century. Wiep van Bunge, however, claims that this libertinage already had strong roots in the French Refuge from the start. He reviews the work of Pierre Bayle, and offers a new approach and a possible solution of the as yet undecided question of how Bayle saw the relation between faith and reason. He positions Bayle way beyond pyrrhonism and much closer to Spinoza than other interpreters do.

The volume is concluded by the contributions of Joke Spaans and Fred van Lieburg. Both are concerned with authors who were theologians and produced new genres of religious literature for a lay audience that was literate in the vernacular. Spaans studies the biography and publications of Johannes Duijkerius, a schoolmaster who was trained as a theologian but who, rather than entering the ministry, became a broker among the established clergy, a wider public interested in vernacular theology, and the very mixed company of people who discussed the implications of new philosophy and scientific discoveries for the traditional Christian worldview. Fred van Lieburg analyses the views of the prominent Reformed minister Wilhelmus à Brakel on the boundaries of Reformed orthodoxy. In the aftermath of the controversies of the later seventeenth century he delineated a 'reasonable religion' and defended it against the rise of 'enthusiasm' in radical pietisms. He paved the way for a newer Protestantism: orthodox and pious, yet polite and egalitarian.

When all is said and done, can we confirm, or perhaps expand upon or modify, Troeltsch's hunch that a new kind of Protestantism developed in the decades around 1700, a Protestantism that was moralized, personalized, interiorized? A Protestantism, in other words, that was to be appropriated by and that benefitted individual Christians, instead of buttressing the confessional state? With a focus on the Dutch Republic, but with our eyes open to developments in Europe and beyond, the contributions to this volume provide the first outlines of an answer, pointing to fruitful lines of approach for further research. A common factor that many contributions hint at is that often it was 
not so much the content of religious doctrine or practice that changed, but rather the circumstances in which this content was articulated or experienced.

We see this, for instance, in the theoretical elaboration of the position of religion in society, as explored by Krop and Nieuwstraten. The philosophers that Krop examines are notable not so much for the criticisms they level against traditional notions of the one and only True Religion, but rather for the conceptualization of the existence of a plurality of religions, none of them true in any absolute sense. Any religion was potentially valid, as long as it satisfied certain requirements. These requirements were defined not dogmatically but ethically: religiously informed piety should breed moral rectitude, and religious worship must serve a politically defined social order. This becomes apparent even more starkly in Nieuwstraten's analysis of the political writings of Boxhorn and their reception by several late-seventeenth-century theologians. Boxhorn held on to the importance of a state religion that promoted social cohesion and offered moral guidance - the religion of a confessional state. However, by making the choice of that religion dependent on the historically evolved customs of society, he seemed to subject theological truth-claims to the demands of political expediency. Each society had its own customs, so each society should also have its own religion. It is striking that this pragmatic argument for confessional religion found resonance among theologians such as Melchior Leydekker and Gerard de Vries, both active in an environment that is usually considered to have been very intransigent in its orthodoxy. In other words, on a theoretical level the real novelty often was the 'agreement to disagree' rather than any change in the content of one's own religious denomination.

Religion could also change in character by moving into new media, even if such a shift was not immediately accompanied by new content. Gierl has shown how exactly the media in which confessional and less confessional concepts of Christianity were expressed effected a shift in the status of those concepts. By moving, first, out into the open arena of learned journals, debate among orthodox and pietist theologians involved a broader public. The proliferation of contributions, also in the vernacular, engendered a change in the mode of debating: the debate itself became historicized as participants attempted to disentangle the immediate past of their particular controversies. The result was that positions of both orthodox Lutheranism and pietism were firmly anchored in public consciousness, and neither could claim exclusive authority over the other. We see this mechanism time and again in the various contexts examined in this book: new media and a new readership meant that religion operated in a new way, even if the content of doctrine and worship (initially) remained more or less the same. The network of sçavants in Utrecht, for instance, charted by Gootjes, created an informal platform on which religious 
truth was juxtaposed with all kinds of knowledge pertinent to both nature and culture. The participants in this network had absolutely no intention to deviate from orthodoxy, yet the result was a disconcerting broadening of the cognitive context in which theology needed to stand its ground - with the concomitant labelling of these sçavants by their adversaries as libertines, atheists, and radical critics. Spaans and Van Lieburg have looked into yet another reconfiguration of the media in which religion took shape: an explosion of the market for catechization, driven not so much by clerical authorities as by a genuine demand originating in lay circles yearning for self-advancement (either spiritually or materially). The immediate result was a steady stream of vernacular theological literature, easily accessible to interested lay people. The example of Brakel shows how this literature could be employed to mould the Reformed reading public into 'reasonable' believers. Another result was the emergence of a 'minor clergy', straddling and dissolving the division between the ordained ministry and the laity, as the example of Johannes Duijkerius illustrates.

A third way that the traditional forms of Christianity seem to have been caught up in a new context lies in their spatial-temporal framing. Weststeijn has alerted us to the way the expanse of North America's eastern coasts energized religious activists of all stripes within the confessional spectrum: whether orthodox Reformed, freethinking minimalist, or spiritualist sectarian, all could hope to find space for their religious ambitions in the New World. All ran up against insurmountable obstacles, but their efforts could be expanded on when missionary zeal and sectarian adventurism really took off over the course of the eighteenth century. At the same time, the bewildering diversity of societies that already peopled newly encountered areas, as well as the interminable variety of religious experiences across the ages, reverberated among the well-informed professionals, the 'elite of the skilled,' back in Europe. Van ' $t$ Hof has foregrounded Romeyn de Hooghe as a perfect case in point: the historical and comparative interests pervading the Hieroglyphica show that even if De Hooghe himself nowhere gives evidence of any deviation from orthodox Reformed Christianity, the mere visual presence of a world of religious diversity outside of the traditional scheme of Old Covenant/New Covenant/Heresy cast a whole new light on the genealogy of True Religion. The same could be said of the 'early modern world history' with which Gisbert Cuper busied himself. The steady accumulation of materials showed, in an ever more accurate way, that there was no obvious relationship between various cultures in the Middle East, in eastern Asia, in southern Asia. Touber has focussed on the early modern antiquarian interest in writing systems to argue for the importance of practical skill, even in such a traditional field as biblical history. As the possibilities of procuring accurate reproductions of scripts continued to increase, the 
impossibility of establishing formal kinship among alphabets in various parts of the world impressed itself on scholars - to the point that they abandoned their ambitions of reducing world history to a past that could be derived from a single, divinely ordained, primeval civilization.

Changes in the theoretical justification of religion, in the media used to communicate religion, and in the spatial-temporal framework encapsulating religion go a long way towards explaining why the communal religion, consolidated in the early seventeenth century, lost its anchoring in the eighteenth century. In the end, it was often the very urgent needs of the moment that forced people into outspoken positions that took stock of the new situation, which had latently been in the making for a long time. The civic religion of Romeyn de Hooghe, sketched by Daudeij, is again a good example: subjecting religious practice to a sacralized, imagined civic community, and doing so in a vernacular genre that had traditionally eschewed delicate social and political themes, was both an innovative and an effective way of redefining religion without touching its content. But Willem Goeree and Arnold Houbraken, no less, were in the business of transforming the framework in which religion could be meaningful. Both being artists like De Hooghe, they broke with every convention in publishing lavishly illustrated, naturalist investigations of the societal embedment of religion, as Israel has shown - while continuously professing their adherence to the tenets of orthodoxy. And Pierre Bayle may have been an enigma, but it is very clear that he set a new standard for the framing of received knowledge. The conscience of the new temporal and spatial limits of the world, of nature and of culture, found a natural home in his Dictionnaire. Moreover, as Van Bunge has argued, even if it is impossible to pinpoint one assertion that confirms Bayle's rejection of the religion of the confessional state, it is precisely in the tortuous layout of his oeuvre that his retreat from religion as it had been defined in the seventeenth century becomes apparent.

So even if most authors in the decades around 1700 did not claim that Christian religion should be abandoned - there was no advocacy of anything approaching secularization, that is - we must conclude that Christians lived their religion in a new awareness of the relativity of their truth-claims and in a newly enlarged world of religious diversity and historical dispersion, and were surrounded by new media propagating an Enlightened religion to an expanding and increasingly literate, and even theologically articulate, popular audience. These developments inevitably redefined the way they themselves, and the communities to which they belonged, related to their religion. This redefinition increasingly distanced this new sense of religious adherence and faith from the religious regimes of the confessional age. It resulted in the creation of a newer Protestantism at the outset of the eighteenth century, which remains 
to be explored in greater detail as part of the 'long Reformations.' All this calls for an approach towards the Enlightenment that acknowledges that the anticlerical discourse long taken as the Enlightenment project is only one segment of a broader spectrum, a spectrum that includes the totality of arguments exchanged over the question of how to reach a new cultural equilibrium between Church and state, religion and the secular, after the fragmentation of European Christendom during the Reformations of the sixteenth century. 